\title{
Impact Of HR Analytics On Training And Development In An Organization Paleti Narendar ${ }^{1}$, Dr. Mridula Mishra ${ }^{2}$ \\ ${ }^{1}$ Research Scholar (Management),Lovely Faculty of Business and Arts, Lovely Professional University \\ ${ }^{2}$ Professor and Head of Department ,Mittal School of Business, Lovely Professional University, Phagwara, Punjab
}

\begin{abstract}
We can observe a shift of training \& development process from traditional method to modern hiring data driven process in modern organization where the HR analytics comes into picture which uses multiple mix of data in Training \& Development. The following study highlights the utilization of HR analytics in the organization as well as focuses on whether the organizations are implementing HR analytics in the Training \& Development process or not. It also helps in how HR analytics is helpful in the effectiveness of Training \& Development process and its cost effectiveness..
\end{abstract}

Keywords:

Training \& Development, HR analytics, HR department,Cost effectiveness

Article Received: 18 October 2020, Revised: 3 November 2020, Accepted: 24 December 2020

\section{Introduction}

As we know that present organizations are facing competition rival continuously due to change in technology as well as business environment. In order to meet those challenges, the organization must train and develop their employees. Organizations must deal with training necessities which is linked up with altering as well as growing internationalization of industry for these purpose individuals need to be prepared with right sort of information and capabilities and also aptitude in order to carry out the allocated responsibilities and also considered to have a massive impact on organizational efficiency. Increase in the expenses of training led to more productivity.

Training and development are about managing and also empowering the people, assets of any business or a firm. Human resource professionals act as strategic partners along with senior managers and leaders by arranging training and development strategies in order to carry out the smooth operations.

\section{Employee Training}

Training is one of the organized ways where the organizations provide development and enhances the quality of new as well as existing employees. It has been viewed as a systematic approach of learning and development which improve individuals. Training employees is about teaching them how to perform the specific task or a procedure.

\section{Employee Development}

Development refers to the activities leading to the acquisition of new knowledge or the skills for the purpose of growing organizations to provide employees along with development programs where they can enhance their capabilities. It is increasing a critical and strategic imperative in the organization in current business environment and organizations need to invest in development of employees in order to maintain employees in the organization.

\section{HR Analytics}

In the modern business environment, there is a presence of large amount of data owing the information age the interpretation usually the organizations have the large amount of data and the task is considered as the large as the data contained is raw. The need to transform this data into the useful information which has resulted in the rapid growth of HR analytics.To identify the best HR talent, various approaches and methods of evaluating the HR have emerged. This concept of evaluating, rating, and gathering intelligence on $\mathrm{HR}$ is known as HR analytics. HR analytics 
contributes the development strategy by creating a benchmark on intelligence gathered about effective HR practices in other organizations which enhances the organizations HR practices.

Effect of training on performance:

Employee training plays a very important role in improving the performance of the employee as well as the productivity. This activity places the organization in better position in order to face the competition and to stay at the top. It is important that organizations need to have continuous policies of training and retaining of employees and thus not to wait for occurrences of skill and performance gaps.

Analytics overview:

Learning analytics has become an important skill which helps to gain an unparallel e-learning experience whether it might be related educational institutions or business employee training in order to create a productive environment in which the employee would develop both traditional as well as digital classrooms which have to be rely on actionable data.

The following data comes from every measurable factor including the feedback of learner, employees or trainees score on test, exams and the amount of time they actually require to complete the course. In addition to these factors such as personal preferences, skill levels and the individual achievements allow the educators to take closer look at how their students are performing

\section{Literature reviews}

\section{Kamel Barbar, Radwan Choughri and Moetaz}

Saubjaki: The following research paper title is "The Impact of HR analytics on the training and development strategy". The following study is based on one of the private sector case study in Lebanon. The authors by this study stated that HR professionals are depended on HR analytics in order to formulate the employee development strategies they also suggested that business should integrate HR professionals and also HR analytics into the process of decision making and development strategy formulation.
Maimuna Muhammad Nda and Dr. Rashad Yazdani Fard:The title of the following research paper is "The impact of employee training and development on employee productivity". The author by this research states that training and development upgrades not only productivity of employees but also of the organization. By this research it also stated that training has enhanced employee's initiative and quality of work, organizations train and develop their workforce to the fullest in which organizations need to enhance their productivity.

Mohammad Raja Abulraheem Salah:The title of the following research paper is "The impact of training and development on employee's performance and productivity". Training and development deals with acquisition of understanding it is a imperatives of human resource management which improves performance at individual, collegial and organizational levels. It also stated that training and development has a positive relationship as well as a positive impact on employees' performance and productivity.

\section{Objectives}

- To know the effectiveness of HR analytics in training and development

- To analyze the changes bought by HR analytics in training and development

- To know the cost effectiveness of HR analytics in training and development

\section{Research Methodology}

The analysis is done with the help of SPSS software after obtaining the answers to the research questionnaire. A sample size of 101 respondents who are undergone the Training programs from a software company that have implemented HR Analytics have been collected.The Mean, Median and Standard Deviation were used as the questionnaire has close ended

questions 
Table 1

GENDER

\begin{tabular}{|c|c|c|c|c|c|}
\hline & & Frequency & Percent & $\begin{array}{c}\text { Valid } \\
\text { Percent }\end{array}$ & $\begin{array}{c}\text { Cumulative } \\
\text { Percent }\end{array}$ \\
\hline \multirow{3}{*}{ Valid } & $\begin{array}{l}\text { FEMAL } \\
\text { E }\end{array}$ & 36 & 35.6 & 35.6 & 35.6 \\
\hline & MALE & 65 & 64.4 & 64.4 & 100.0 \\
\hline & Total & 101 & 100.0 & 100.0 & \\
\hline
\end{tabular}

Fig. 1

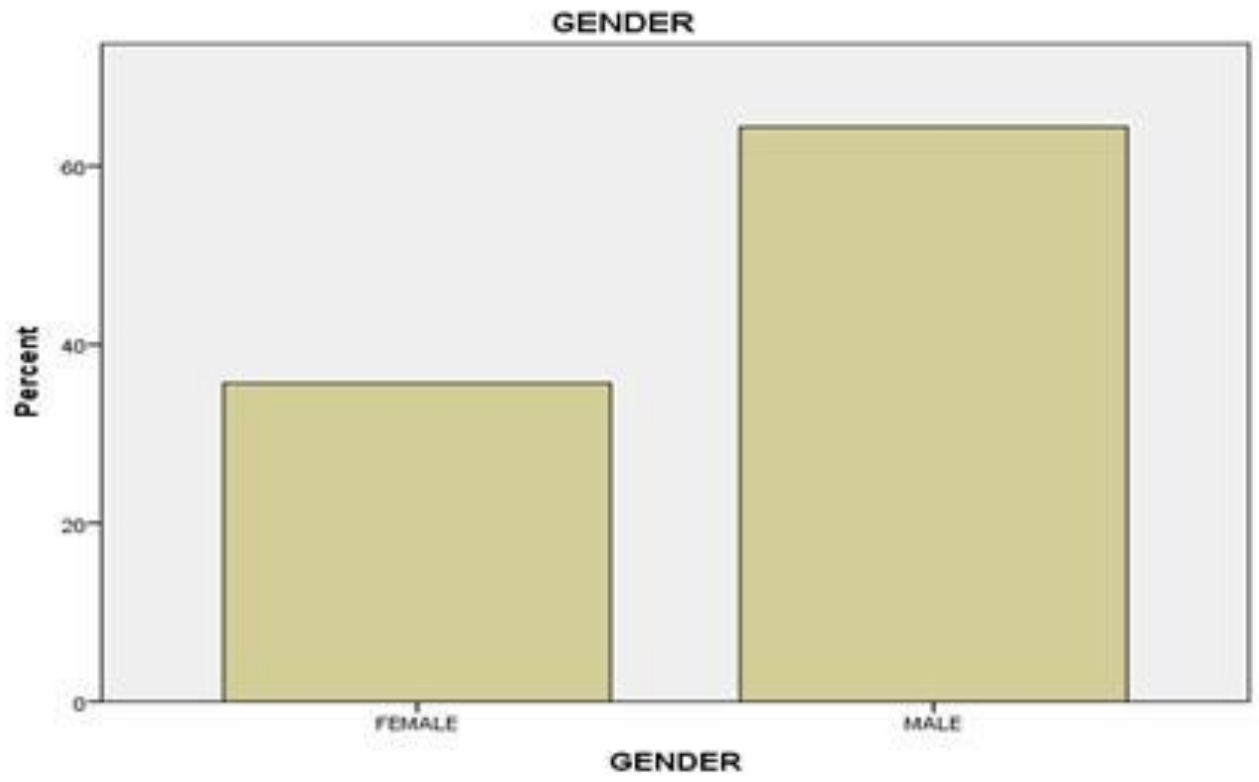

Table 2

Have you undergone training and development

\begin{tabular}{|l|r|r|r|r|}
\hline & $\begin{array}{c}\text { Frequenc } \\
\mathrm{y}\end{array}$ & Percent & Valid Percent & $\begin{array}{c}\text { Cumulative } \\
\text { Percent }\end{array}$ \\
\hline $\begin{array}{l}\text { Valid } \\
\text { Yes }\end{array}$ & 101 & 100 & 100 & 100.0 \\
\hline
\end{tabular}


Table 3 Type of training and development imparted

\begin{tabular}{|c|c|c|c|c|c|}
\hline & & $\begin{array}{c}\text { Frequen } \\
\text { cy }\end{array}$ & $\begin{array}{c}\text { Percen } \\
\mathrm{t}\end{array}$ & $\begin{array}{l}\text { Valid } \\
\text { Percent }\end{array}$ & $\begin{array}{l}\text { Cumulativ } \\
\text { e Percent }\end{array}$ \\
\hline \multirow{23}{*}{$\begin{array}{l}\text { Vali } \\
\text { d }\end{array}$} & Management & 2 & 2.0 & 2.0 & 2.0 \\
\hline & Training & & & & \\
\hline & Management & 4 & 4.0 & 4.0 & 5.9 \\
\hline & Training; & & & & \\
\hline & Presentation skill & & & & \\
\hline & Management & 5 & 5.0 & 5.0 & 10.9 \\
\hline & $\begin{array}{l}\text { Training; Technical } \\
\text { skill }\end{array}$ & & & & \\
\hline & Management & 1 & 1.0 & 1.0 & 11.9 \\
\hline & Training; Technical & & & & \\
\hline & skill; Presentation & & & & \\
\hline & skill & & & & \\
\hline & Technical Training & 1 & 1.0 & 1.0 & 12.9 \\
\hline & Technical Training; & 49 & 48.5 & 48.5 & 61.4 \\
\hline & Management & & & & \\
\hline & Training & & & & \\
\hline & Technical Training; & 6 & 5.9 & 5.9 & 67.3 \\
\hline & Management & & & & \\
\hline & Training; & & & & \\
\hline & Presentation skill & & & & \\
\hline & Technical Training; & 6 & 5.9 & 5.9 & 73.3 \\
\hline & Management & & & & \\
\hline & Training; Technical & & & & \\
\hline & skill & & & & \\
\hline
\end{tabular}




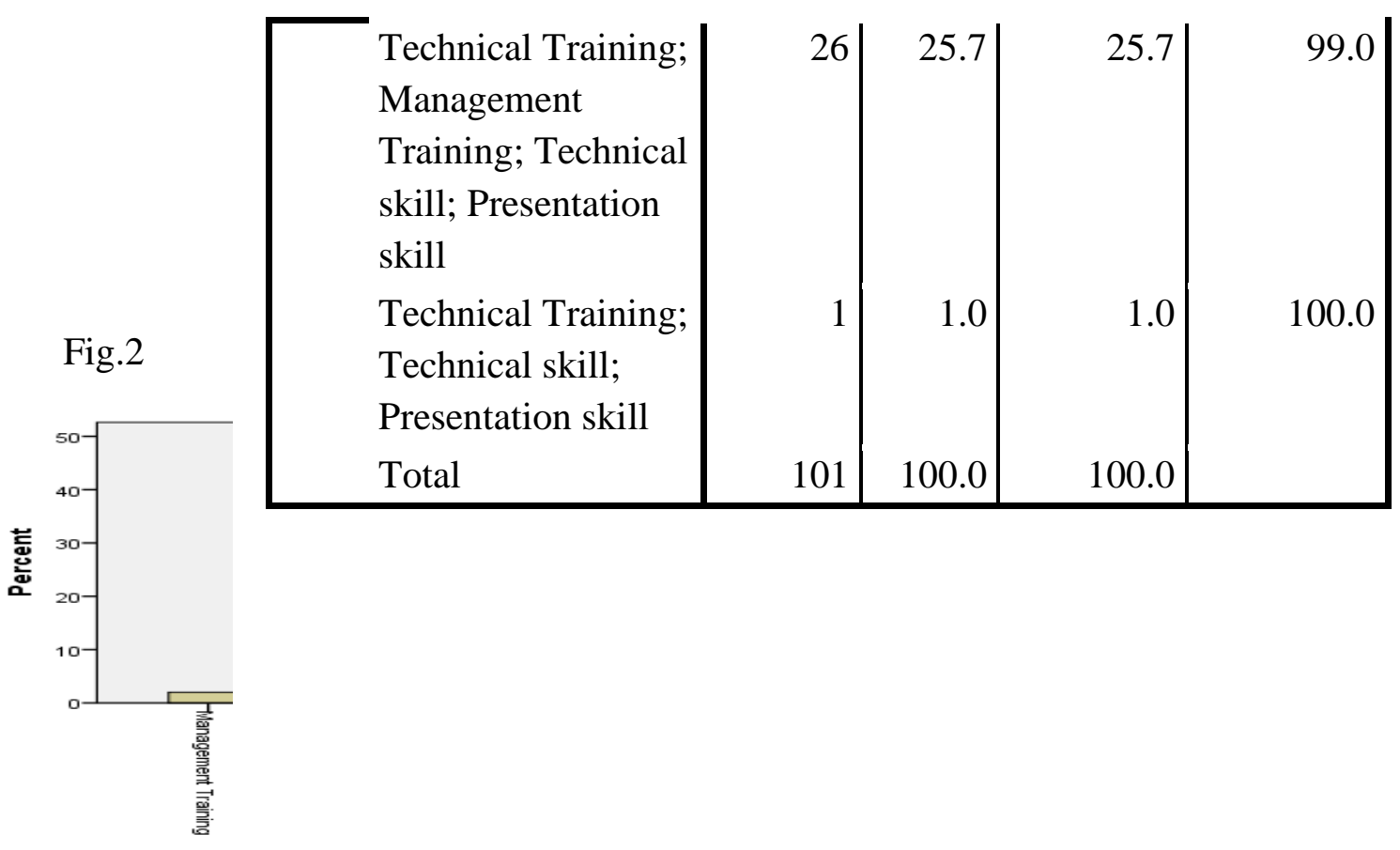

Table 4

Aware of HR Analytics

\begin{tabular}{|c|r|r|r|r|}
\hline & $\begin{array}{c}\text { Frequenc } \\
\text { y }\end{array}$ & Percent & $\begin{array}{c}\text { Valid } \\
\text { Percent }\end{array}$ & $\begin{array}{c}\text { Cumulative } \\
\text { Percent }\end{array}$ \\
\hline Yes & 97 & 96.0 & 96.0 & 96.0 \\
Valid No & 4 & 4.0 & 4.0 & 4.0 \\
Total & 101 & 100.0 & 100.0 & \\
& & & & 100.0 \\
\hline
\end{tabular}

Table 5

Organization implement HR Analytics

\begin{tabular}{|c|r|r|r|r|}
\hline & $\begin{array}{c}\text { Frequenc } \\
\text { y }\end{array}$ & Percent & $\begin{array}{c}\text { Valid } \\
\text { Percent }\end{array}$ & $\begin{array}{c}\text { Cumulative } \\
\text { Percent }\end{array}$ \\
\hline Yes & 97 & 96.0 & 96.0 & 96.0 \\
Valid No & 4 & 4.0 & 4.0 & 4.0 \\
Total & 101 & 100.0 & 100.0 & \\
& & & & 100.0 \\
\hline
\end{tabular}


Table 6

Use HR analytics in training and development

\begin{tabular}{|c|c|c|c|c|c|}
\hline & & $\begin{array}{c}\text { Frequenc } \\
\mathrm{y}\end{array}$ & Percent & $\begin{array}{c}\text { Valid } \\
\text { Percent }\end{array}$ & $\begin{array}{c}\text { Cumulative } \\
\text { Percent }\end{array}$ \\
\hline \multirow{5}{*}{ Valid } & Yes & 98 & 97.0 & 97.0 & 97.0 \\
\hline & No & 3 & 3.0 & 3.0 & 3.0 \\
\hline & & 101 & 100.0 & 100.0 & \\
\hline & Total & & & & \\
\hline & & & & & 100.0 \\
\hline
\end{tabular}

Table 7

$\mathrm{T}$ and $\mathrm{D}$ increases efficiency in employee

\begin{tabular}{|l|r|r|r|r|}
\hline & $\begin{array}{c}\text { Frequenc } \\
\text { y }\end{array}$ & Percent & $\begin{array}{c}\text { Valid } \\
\text { Percent }\end{array}$ & $\begin{array}{c}\text { Cumulative } \\
\text { Percent }\end{array}$ \\
\hline Valid Yes & 101 & 100.0 & 100.0 & 100.0 \\
\hline
\end{tabular}

Table 8

Changes after implementation of HR Analytics in T\&D

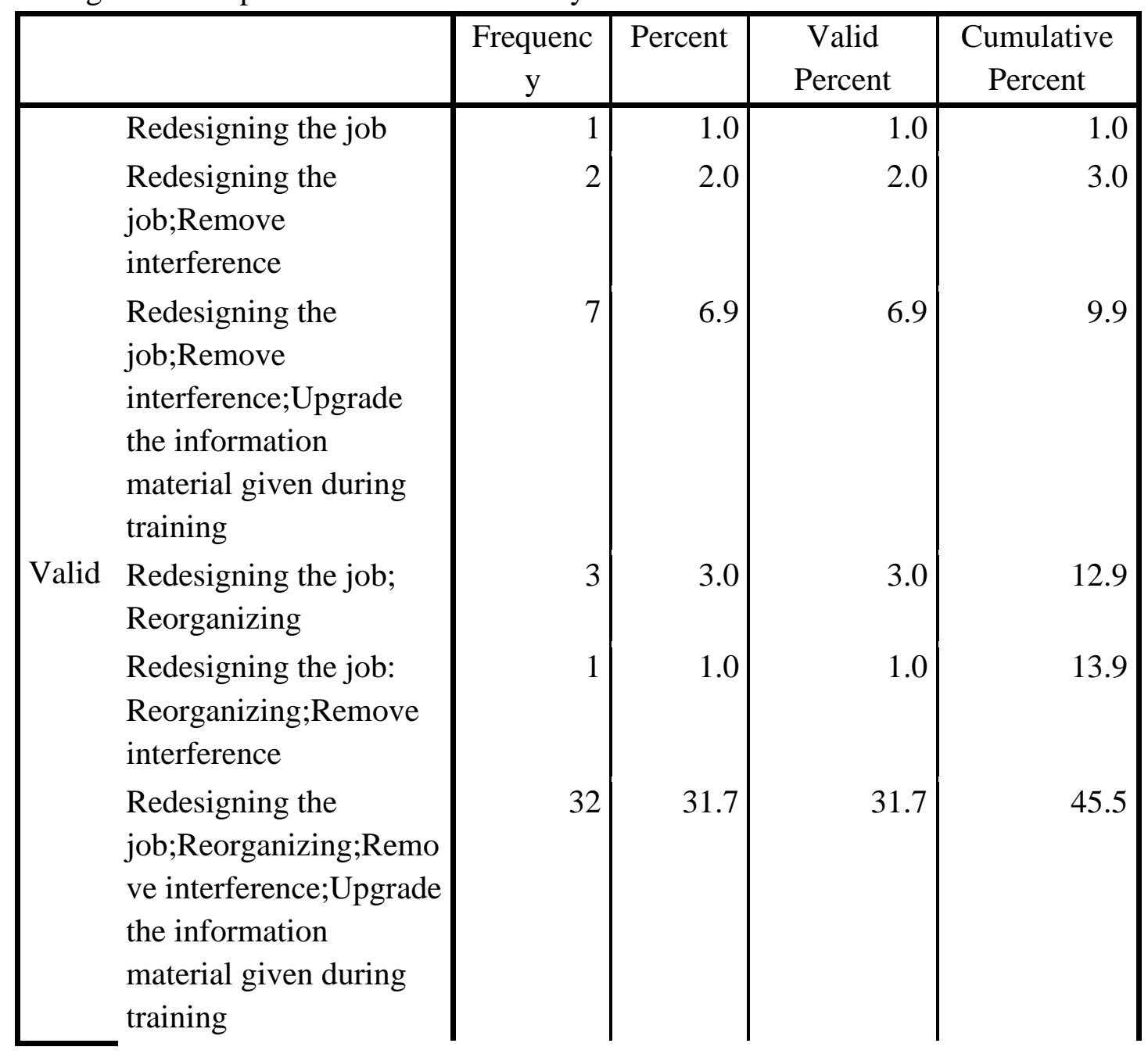




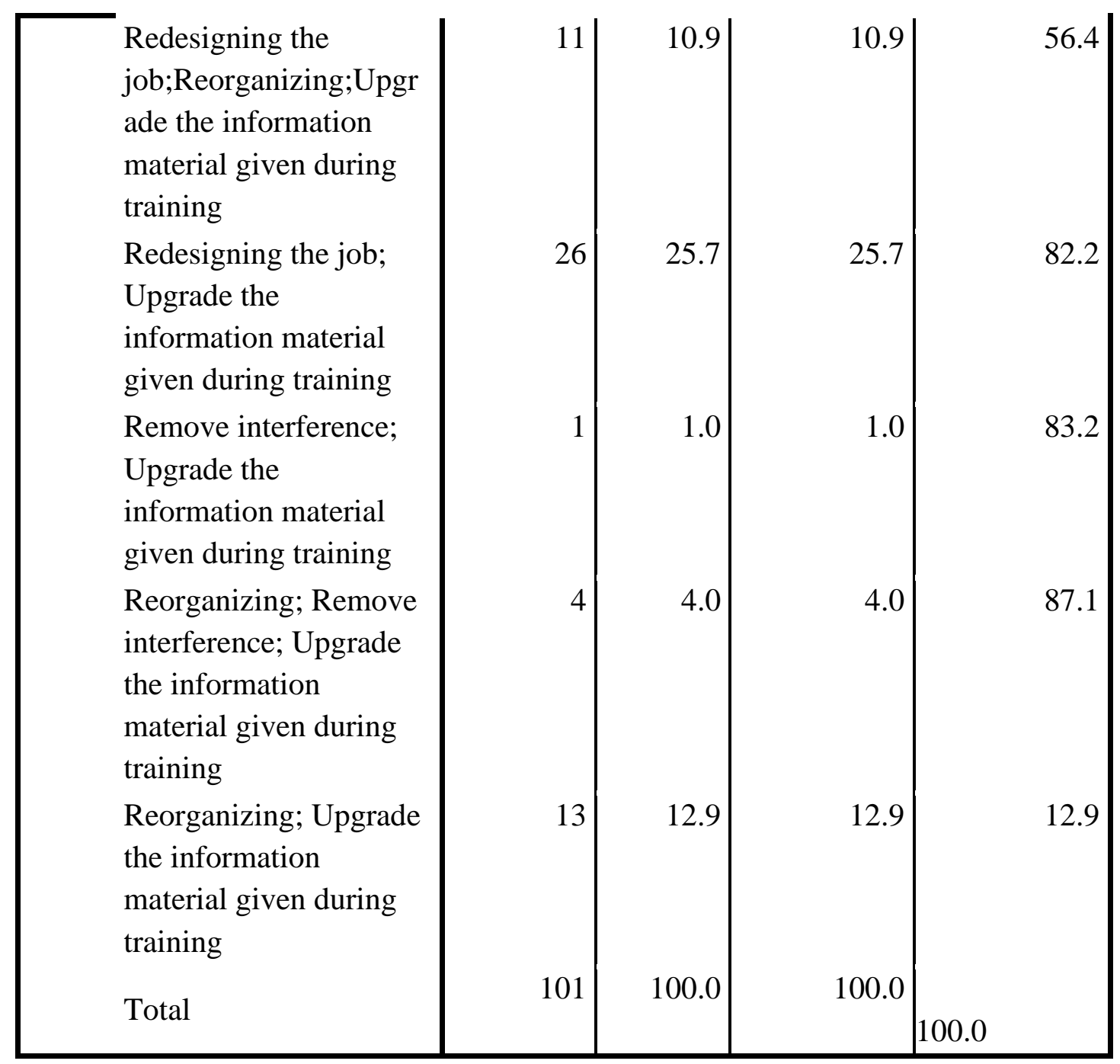

Fig. 3

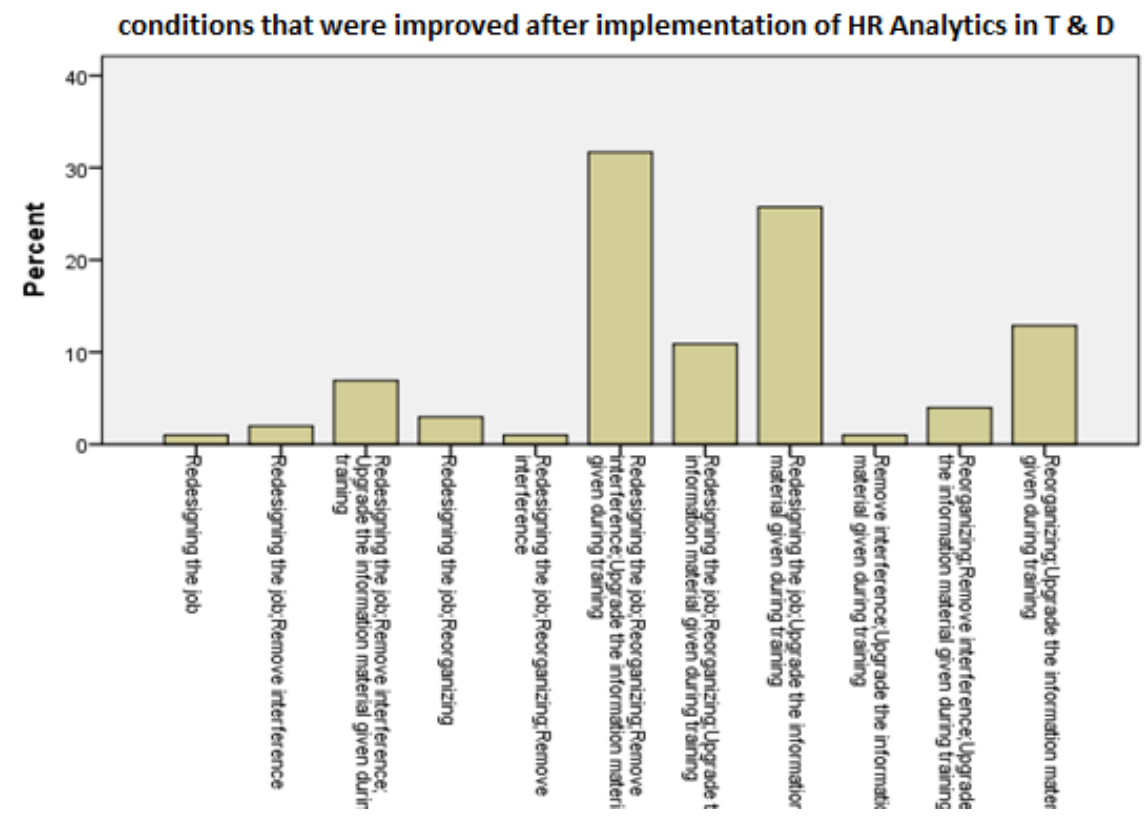


Table 9

HR Analytics helped to increase both quality and efficiency of employees

\begin{tabular}{|l|r|r|r|r|}
\hline & $\begin{array}{r}\text { Frequenc } \\
\mathrm{y}\end{array}$ & Percent & \multicolumn{1}{|c|}{$\begin{array}{c}\text { Valid } \\
\text { Percent }\end{array}$} & $\begin{array}{c}\text { Cumulative } \\
\text { Percent }\end{array}$ \\
\hline Neutral & 2 & 2.0 & 2.0 & 2.0 \\
Agree & 58 & 57.4 & 57.4 & 59.4 \\
strongly & 41 & 40.6 & 40.6 & 40.6 \\
Valid agree & 101 & 100.0 & 100.0 & \\
Total & & & & \\
\hline
\end{tabular}

Table 10

HR Analytics Focus on developing teamwork

\begin{tabular}{|l|r|r|r|r|}
\hline & $\begin{array}{c}\text { Frequenc } \\
\text { y }\end{array}$ & Percent & $\begin{array}{c}\text { Valid } \\
\text { Percent }\end{array}$ & $\begin{array}{c}\text { Cumulative } \\
\text { Percent }\end{array}$ \\
\hline Valid Yes & 101 & 100.0 & 100.0 & 100.0 \\
\hline
\end{tabular}

Table 11

Do you recommend implementing HR Analytics

\begin{tabular}{|c|c|c|c|c|c|}
\hline & & $\begin{array}{c}\text { Frequenc } \\
\mathrm{y}\end{array}$ & Percent & $\begin{array}{c}\text { Valid } \\
\text { Percent }\end{array}$ & $\begin{array}{c}\text { Cumulative } \\
\text { Percent }\end{array}$ \\
\hline \multirow{5}{*}{ Valid } & Yes & 99 & 98.0 & 98.0 & 98.0 \\
\hline & No & 2 & 2.0 & 2.0 & 2.0 \\
\hline & & 101 & 100.0 & 100.0 & \\
\hline & Total & & & & \\
\hline & & & & & 100.0 \\
\hline
\end{tabular}

Table 12

Cost of T and D before HR Analytics

\begin{tabular}{|l|r|r|r|r|}
\hline & $\begin{array}{c}\text { Frequenc } \\
\text { y }\end{array}$ & Percent & $\begin{array}{c}\text { Valid } \\
\text { Percent }\end{array}$ & $\begin{array}{c}\text { Cumulative } \\
\text { Percent }\end{array}$ \\
\hline Very high & 41 & 40.6 & 40.6 & 40.6 \\
High & 55 & 54.5 & 54.5 & 95.0 \\
Average & 1 & 1.0 & 1.0 & 96.0 \\
Valid Low & 1 & 1.0 & 1.0 & 97.0 \\
don't & 3 & 3.0 & 3.0 & 3.0 \\
know & & & & \\
Total & 101 & 100.0 & 100.0 & \\
\hline
\end{tabular}




\section{Findings :}

1. There is certainly an improvement in the Training \& Development with the help of HR Analytics

2. HR Analytics have helped in redesigning the job and in up gradation of syllabus as per the latest organization requirements.

3. HR Analytics is helpful in knowing the effectiveness of Training \& Development in analytical manner

4. HR Analytics has reduced the cost of Training \& Development

\section{Suggestions}

There is need to improve the usage of HR Analytics in Indian Industry. In India, HR Analytics is confined largely to IT and Pharma Sectors, however, it can be applied in other sectors like in foreign nations like USA and UK, it is applied in sports also and it has brought notable changes wherever it is applied. The top level management should also see it as a permanent solution and should train their employees in HR Analytics.

\section{REFERENCES:}

[1] Sujeet Kumar, Ashish Kumar Gupta. (2004). A study on recruitment and selection process with

referencehttps://www.researchgate.net/publi cation/268210664

[2] Biriowu, C. S., and Nissi Linda Kalio(2020). "TALENT ANALYTICS AND EMPLOYEE RETENTION IN NIGERIA ORGANIZATIONS."International Journal of Human Resources Management (IJHRM) 9.3, Apr-May 2020; 1-12
[3] Dr. SnehaManikar. (2014). A critical study on recruitment and selection with reference toHRconsultingfirms.https://www.worldwid ejournals.com/paripex/recent_issues

[4] Gouda, Hanan. "Investigating the Influence of Leadership on Employees' Loyalty in the Private Education Sector in Egypt." International Journal of Humanities and Social Sciences (IJHSS) 7.6, Oct-Nov 2018; 133146.

[5] IJMRR/ October 2014/ Volume 4/Issue 10/Article No-5/996-1006 Syamala Devi Bhoganadamet.al./ International Journal of Management Research \& Review

[6] Jaswani, S. "Do intrinsic motivation influence turnover intention? structural equation modeling approach among technical faculty members." International Journal of Business and General Management 20 (2016).

[7] Anushyayogarajan, Dr. S.N. Sundararajan, (2017). A study on recruitment and selection process organization with the help of recruiting agency. http://www.ijariie.com/AdminUploadPdf

[8] Lakshmi, P., and P. Pratap. "HR analytics-a strategic approach to HR effectiveness." International Journal of Human Resource Management and Research 6.3 (2016): 2128.

[9] Madhavi Lakshmi, P., and P. Siva Pratap. "HR Analytics-a Strategic Approach to HR Effectiveness." International Journal of Human Resource Management and Research (IJHRMR) ISSN (P) (2016): 2249-6874. 